\title{
Select neuropeptides and their G-protein coupled receptors in Caenorhabditis elegans and Drosophila melanogaster
}

\author{
William G. Bendena ${ }^{1}$, , Jason Campbell ${ }^{1}$, Lian Zara ${ }^{1}$, Stephen S. Tobe ${ }^{2}$ and lan D. Chin-Sang ${ }^{1}$ \\ 1 Department of Biology, Queen's University, Kingston, ON, Canada \\ ${ }^{2}$ Cell and Systems Biology, University of Toronto, ON, Canada
}

\section{Edited by:}

Joe Hull, USDA Agricultural Research

Service, USA

Reviewed by:

Shinji Nagata, University of Tokyo,

Japan

Stephen Garczynski, United States

Department of Agriculture, USA

\section{*Correspondence:}

William G. Bendena, Department of Biology, Queen's University, Kingston, ON, Canada K7L 3N6.

e-mail:william.bendena@queensu.ca
The G-protein coupled receptor (GPCR) family is comprised of seven transmembrane domain proteins and play important roles in nerve transmission, locomotion, proliferation and development, sensory perception, metabolism, and neuromodulation. GPCR research has been targeted by drug developers as a consequence of the wide variety of critical physiological functions regulated by this protein family. Neuropeptide GPCRs are the least characterized of the GPCR family as genetic systems to characterize their functions have lagged behind GPCR gene discovery. Drosophila melanogaster and Caenorhabditis elegans are genetic model organisms that have proved useful in characterizing neuropeptide GPCRs. The strength of a genetic approach leads to an appreciation of the behavioral plasticity that can result from subtle alterations in GPCRs or regulatory proteins in the pathways that GPCRs control. Many of these invertebrate neuropeptides, GPCRs, and signaling pathway components serve as models for mammalian counterparts as they have conserved sequences and function. This review provides an overview of the methods to match neuropeptides to their cognate receptor and a state of the art account of neuropeptide GPCRs that have been characterized in $D$. melanogaster and $C$. elegans and the behaviors that have been uncovered through genetic manipulation.

Keywords: invertebrate neuropeptides, G-protein coupled receptor, insects, nematodes, Caenorhabditis elegans, Drosophila melanogaster

\section{INTRODUCTION}

Animals respond to environmental cues through alteration of neural circuits that modify behavior and metabolism. The mechanism underlying the regulation of the neural circuit in response to a simple sensory cue is extremely complex and difficult to disentangle in mammals. The nematode Caenorhabditis elegans offers an excellent model organism to analyze neural circuit function. $C$. elegans is $1.3 \mathrm{~mm}$ in length and has several desirable features. The hermaphrodite has 959 somatic cells that form different organs and tissues including muscle, hypodermis, intestine, reproductive organs and glands, and the nervous system. The nervous system comprises 302 neurons whose identity and connections have been defined by morphology and ablation studies. C. elegans is also transparent such that in vivo fluorescent proteins and dyes can be used to visualize gene expression and fat metabolism in the living animal. The advantage over other systems is that alterations within a functional neuron can be studied in the context of the whole organism and rather than measuring changes in fluorescence, the actual behavioral response of the animal can be monitored directly. Drosophila melanogaster is more complex in terms of physical organization and behaviors. Some 90,000 neurons of the brain reflect a similar level of complexity as the different neural cell types in humans (Venken et al., 2011). D. melanogaster, like C. elegans, has a variety of genetic tools that allow for forward (mutagenic screens) and reverse (targeted gene disruption) genetics. The Drosophila UAS-Gal4 system (and derivatives there of) enable the use of specific promoters to target reporter genes, structural genes (for overexpression), or expression of ds RNA for selected gene inhibition (RNAi) to specific larval or adult tissues (Seroude, 2002). D. melanogaster and C. elegans have recently emerged as excellent paradigms for identifying the cellular mechanisms underlying human disease. Disease models are possible if the disease can be explained in molecular terms. Both of these non-mammalian genetic models have a strong record of uncovering disease-related genes that have orthologs in the human genome. These include the uncovering of genes involved in Alzheimer's disease (Sundaram and Greenwald, 1993; De Strooper et al., 1999; Chakraborty et al., 2011), Parkinson's (Feany and Bender, 2000), diabetes type II (Nakae et al., 2002), polyglutamine and other triplet repeat expansion diseases (Campesan et al., 2011), depression (Ranganathan et al., 2001; Pandey and Nichols, 2011), epilepsy, and schizophrenia (O'Kane, 2011).

Drosophila melanogaster and C. elegans produce and store most classical small molecule neurotransmitters in synaptic vesicles that cluster for release at pre-synaptic sites. These include acetylcholine, $\gamma$-aminobutyric acid (GABA), the biogenic amines octopamine, tyramine, dopamine, and serotonin (5-hydroxytryptamine) and glutamate (Bargmann, 2006) function in conjunction with neuropeptides that are produced as precursor proteins that are packed with processing enzymes and stored in large dense core vesicles 
in the trans-Golgi network. Release of neuropeptide-containing dense core vesicles is not restricted to nerve terminals and can occur at both axons and dendrites. In C. elegans, 113 neuropeptide genes have been identified that potentially produce 250 neuropeptides. These are classified into three groups: the insulin-like peptides (40 ins genes), the FMRFamide-related/like peptides (31 FaRP or $f l p$ genes), and the neuropeptide-like peptides (42 nlp genes; Nathoo et al., 2001). Two recent reviews summarize the synthesis, processing, and function of $C$. elegans neuropeptides (Husson et al., 2007; Li and Kim, 2008). In D. melanogaster, 119 neuropeptide genes have been predicted with 46 neuropeptide families characterized biochemically from 19 precursors (Clynen et al., 2010). In C. elegans, there are over 1100 G-protein coupled receptors (GPCRs) with approximately 100 thought to be specific for neuropeptides (Bargmann, 1998). D. melanogaster has approximately 160 GPCRs (far less than C. elegans with 44 exhibiting characteristics consistent with peptide ligand receptors (Hewes and Taghert, 2001). In both organisms, very few GPCRs have been matched with their respective neuropeptides and much less is known as to how each neuropeptide GPCR functions in neurotransmission or behavior. GPCRs can be separated structurally into several classes or subfamilies. The largest of these are the rhodopsin-like which are activated by small ligands and peptides. The secretin class of GPCRs have large extracellular domains that selectively bind glycoproteins. The metabotropic glutamate/pheromone GPCRs have domains that share sequence similarity with periplasmic binding proteins of bacteria involved in the transport of ions, amino acids, sugars, and peptides. The adhesion and frizzled class of GPCRs also have unique N-terminal binding domains with unique binding properties (Fredriksson et al., 2003; Krishnan et al., 2012). Given the diversity of GPCR types and varied functions this review focuses on some of the genetic and molecular techniques that have been used to specifically deorphan neuropeptide GPCRs in C. elegans and D. melanogaster and decipher their role in regulating behavior and physiology.

\section{MATCHING NEUROPEPTIDES TO ORPHAN RECEPTORS METHODOLOGY}

Only a limited number of reverse pharmacological approaches have been applied to match a peptide ligand to its receptor (i.e., deorphanization) in D. melanogaster and C. elegans. All approaches are based on expression of the GPCR in a membrane system that will complete a signaling pathway that can be assayed. One of the more common assays used to de-orphan GPCRs is the GTP $\gamma \mathrm{S}$ assay (Larsen et al., 2001). The GTP $\gamma$ S assay is one of the most sensitive assays for screening GPCRs and is widely used to characterize full and partial agonists and antagonists. In this assay, the GPCR of interest is expressed in mammalian cells such as Chinese hamster ovary (CHO) or human embryonic kidney (HEK293) cells. The plasma membrane replete with the recombinant GPCR of interest is purified and incubated with GDP and a potential neuropeptide ligand. A radiolabeled non-hydrolyzable GTP analog $\left[{ }^{35} \mathrm{~S}\right] \mathrm{GTP} \gamma \mathrm{S}$, is then added. The premise of the assay is that if the neuropeptide has activated the receptor, the G-protein $\alpha$-subunit exchanges GDP for GTP or in this case $\left[{ }^{35} \mathrm{~S}\right] \mathrm{GTP} \gamma \mathrm{S}$ which accumulates in the membrane and is easily measured. A second type of assay monitors cAMP levels. In this case, a receptor expressed in mammalian cells can be activated by adding a neuropeptide to the culture media. Upon activation, if exchange of GDP to GTP occurs using a G $\alpha_{s}$ subunit, adenylate cyclase activity will be stimulated, converting ATP to cAMP. Conversely, if the GDP to GTP exchange occurs using a $\mathrm{G} \alpha_{\mathrm{i}}$ subunit, adenylate cyclase is inhibited, and cAMP levels decline. In practice, a reporter construct that provides a promoter with multiple cAMP response elements controlling expression of the gene luciferase is co-transfected into cells with the receptor. Enhanced expression of luciferase occurs when cAMP increases. Luciferase catalyzes the oxidation of the firefly specific substrate, D-luciferin, to produce light which can be directly measured. If signaling occurs through $\mathrm{G} \alpha_{i}$, which depresses cAMP levels, cells can be treated with forskolin (which activates adenylate cyclase) prior to neuropeptide application. In this case, cAMP levels can be measured in cell extracts by incubation with a biotinylated-anti-cAMP antibody and a anti-cAMP antibody coupled to an acceptor bead. Streptavidin-coupled to a donor bead is then added to complex with biotin. Excitation of the donor bead with a laser $(680 \mathrm{~nm})$ produces singlet oxygen which can travel up to $200 \mathrm{~nm}$ and excite the cAMP - antibody bound acceptor bead in the complex. The acceptor bead then emits light which can be directly measured. Intracellular $\mathrm{Ca}^{2+}$ can also be used as a measure of GPCRs that couple through $\mathrm{G}_{\mathrm{q}}$. $\mathrm{G}_{\mathrm{q}}$ activates phospholipase $C \beta$ which generates inositol triphosphate and diacylglycerol. Inositol triphosphate activates release of intracellular $\mathrm{Ca}^{2+}$ stores from the endoplasmic reticulum. $\mathrm{Ca}^{2+}$ can be measured by $\mathrm{Ca}^{2+}$ sensitive indicators such as Fluo-4. Alternatively, cells can be co-transfected with a gene that expresses apoaequorin. In the presence of the cofactor coelenterazine, a complex is formed that generates light proportional to the quantity of $\mathrm{Ca}^{2+}$. The relative simplicity of these assays has resulted in their widespread use in matching neuropeptides to their GPCRs, although the expression of C. elegans GPCRs in mammalian cells has encountered a number of pitfalls. For example, stable cell lines expressing some GPCRs cannot be generated because of toxicity problems. In addition, some GPCRs appear to be active only if cultured cells are incubated at $28^{\circ} \mathrm{C}$ rather than the normal $37^{\circ} \mathrm{C}$ (Harada et al., 1987; Geary et al., 1999; Kubiak et al., 2003a,b).

Drosophila melanogaster GPCRs have also been de-orphaned using a $\beta$-arrestin2-green fluorescent protein (GFP) translocation assay (Johnson et al., 2003). In this assay, following ligandGPCR interaction in mammalian cells, $\beta$-arrestin2-GFP translocates from the cytoplasm to the cell membrane or receptor-bearing endosomes as part of termination of signaling (Barak et al., 1997).

G-protein coupled receptors of both $C$. elegans and $D$. melanogaster have also been expressed in Xenopus laevis oocytes along with a G-protein-gated inward rectifying potassium channel (GIRK; Harada et al., 1987). Gating results from release of the $G \beta \gamma$ subunits, which, upon receptor activation, then interact with GIRK. Measurement is through whole cell voltage-clamp recordings.

Caenorhabditis elegans GPCRs have been expressed in the pharynx of $C$. elegans by creating a transgenic animal with a GPCR construct that is under the control of a heat shock promoter. Action potentials are measured by placing a microelectrode into an exposed terminal pharyngeal bulb. For C. elegans neuropeptide receptor-1 (NPR-1), this method gave slightly different results than 
the Xenopus assay when the receptor was tested with several peptides (see below). Human somatostatin receptor and chemokine receptor 5 (CCR5) have been expressed in C. elegans nociceptive neurons ASH and ADL by transformation of the genes under the control of the gpa-11 promoter. Transgenic animals showed an avoidance response to the cognate peptide placed between the worms and an attractant (Teng et al., 2006). This study has been extended to show that animals expressing CCR5 in nociceptive neurons will avoid Escherichia coli that expressed the natural ligand MIP-1 $\alpha$ (Teng et al., 2008). As a cautionary note, this approach may only be applicable to non-modified peptides such as MIP- $1 \alpha$ because $E$. coli does not have the enzymes necessary for some modifications, such as C-terminal amidation that some neuropeptides require for activity.

Despite the techniques outlined above, only a very small number of C. elegans and D. melanogaster receptors have been matched to their cognate ligand. At present, most families of known neuropeptides have been matched to receptors in D. melanogaster (Hewes and Taghert, 2001; Johnson et al., 2003; Clynen et al., 2010). The de-orphaning of C. elegans neuropeptide receptors has not been as rapid as in D. melanogaster. However, some of the C. elegans receptors that have been studied have provided better insights into components of the signal transduction pathways. Both model organisms though have advantages in that transgenic animals can be generated that overproduce neuropeptides or GPCRs and the availability of mutants that give rise to specific phenotypes that result from the suppression of neuropeptide and/or GPCR-linked functions.

\section{COMPARING FUNCTION OF STRUCTURALLY CONSERVED PEPTIDES AND RECEPTORS IDENTIFIED IN DROSOPHILA AND CAENORHABDITIS}

Insect systems have proven invaluable in revealing primary peptide structures that define many neuropeptide families and for developing in vitro physiological assays that provide clues to in vivo functions. The signal transduction pathways for most neuropeptides though are only vaguely understood beyond their interaction with their cognate receptor. Genetic systems such as D. melanogaster and $C$. elegans are now extending our understanding of the steps between neuropeptide release to final physiological action. Many of these peptide-GPCR interactions lead to conserved functions. For example, allatostatin-like peptides appear to influence foraging behavior in D. melanogaster and C. elegans. These systems have also been instrumental in uncovering additional neuropeptide and neuropeptide GPCR functions.

\section{NEUROPEPTIDE F, NPY/NPF PEPTIDES, AND RECEPTORS}

In vertebrates, a 36 amino acid neuropeptide Y (NPY) functions as a neuromodulator to stimulate feeding behavior (Clark et al., 1984; Kalra, 1997). Roles of vertebrate NPY include suppression of responsiveness to adverse stimuli and in promotion of food search and acquisition under adverse conditions (Thorsell and Heilig, 2002). Destruction of NPY-expressing neurons in mice results in starvation of the animals (Pedrazzini, 2004). NPY is thought to work through a specific NPY receptor, to repress the activity of inhibitory neural circuits that then promotes feeding behavior (Klapstein and Colmers, 1993; Browning and Travagli, 2003).
In invertebrates, neuropeptide $\mathrm{F}$ is an ortholog of vertebrate NPY but differs in a C-terminal phenylalanine rather than tyrosine (Brown et al., 1999). Drosophila NPF (DromeNPF) is expressed in the brain and midgut of larvae and adults (Brown et al., 1999). A single receptor, Drome NPF receptor (DromeNPFR) has been identified through expression of the receptor in mammalian cells and binding assays (Garczynski et al., 2002; Table 1). In common with vertebrate NPY, DromeNPF, and its receptor have been associated with the control of social and feeding behaviors. DromeNPF levels are high in larvae, when they remain attracted to food, then fall to lower levels in subsequent developmental stages in which feeding is reduced. Overexpression of the DromeNPFR at later developmental stages encourages feeding behaviors that differ from wild type, whereas underexpression of DromeNPFR leads to a food aversion response in earlier larvae that would normally feed (Wu et al., 2003). Food-associated memory is promoted by starvation and inhibited by satiety in Drosophila. Stimulation of neurons that express DromeNPF mimics food deprivation and promotes memory performance in satiated flies. This memory performance requires the expression of the DromeNPFR in six dopaminergic neurons whereas blocking these neurons releases memory performance in satiated flies and suppresses memory performance in hungry flies. This suggests that dopamine and DromeNPF act together to coordinate memory performance, based on nutritional status (Krashes et al., 2009). DromeNPF also functions in flyaversive responses to a variety of stressors. NPF appears to act antagonistically to insulin signaling systems in regulating aversive responses (Wu et al., 2005). In aversion responses, DromeNPF suppresses PAIN neurons through attenuation of transient receptor potential (TRP) channel-induced neuronal excitation (Xu et al., 2010). iDromeNPF signaling has been implicated in a wide range of behaviors and has recently been shown to have a modulatory effect on fly aggression. Drug-induced increases of 5hydroxytryptamine (serotonin) amplify aggression amongst flies, whereas silencing of the serotonergic circuits leads to a lack of response following application of exogenous serotonin; however, the aggression response still exists. Silencing of the DromeNPF circuit leads to an increase in fly aggression, showing that serotonin and DromeNPF signaling systems act together to regulate fly aggression (Dierick and Greenspan, 2007). The DromeNPF signaling pathways also modulate acute ethanol sensitivity (Wen et al., 2005) and appear to have a male-specific function in courtship behavior. DromeNPF also has a possible role in circadian rhythms (Lee et al., 2006) and is potentially involved in the control of evening activity (Hermann et al., 2012). The signaling pathways regulating these later phenotypes are still poorly understood.

The C. elegans GPCR (C39E.6.6 = Caeel npr-1) shares homology with the vertebrate NPY receptor family. Caeel $n p r-1$ is expressed in at least 20 neurons. Two natural alleles of NPR-1 that differ by a single amino acid at position 215 , which likely affects G-protein signaling show two behavioral phenotypes termed "solitary" versus "social." Animals, typified by the N2 Bristol strain used in most labs as a wild type strain, express Caeel $n p r-1$ with valine at position 215 (Caeel $n p r-1215 \mathrm{~V}$ ). This Caeel $n p r-1$ allele results in animals with reduced locomotory activity on a bacterial lawn and they disperse over the lawn as solitary individuals. Animals such as the Hawaiian isolate CB4856, express Caeel npr-1 with 
Table 1 | Receptor-ligand interaction affinities as measured in heterologous expression systems.

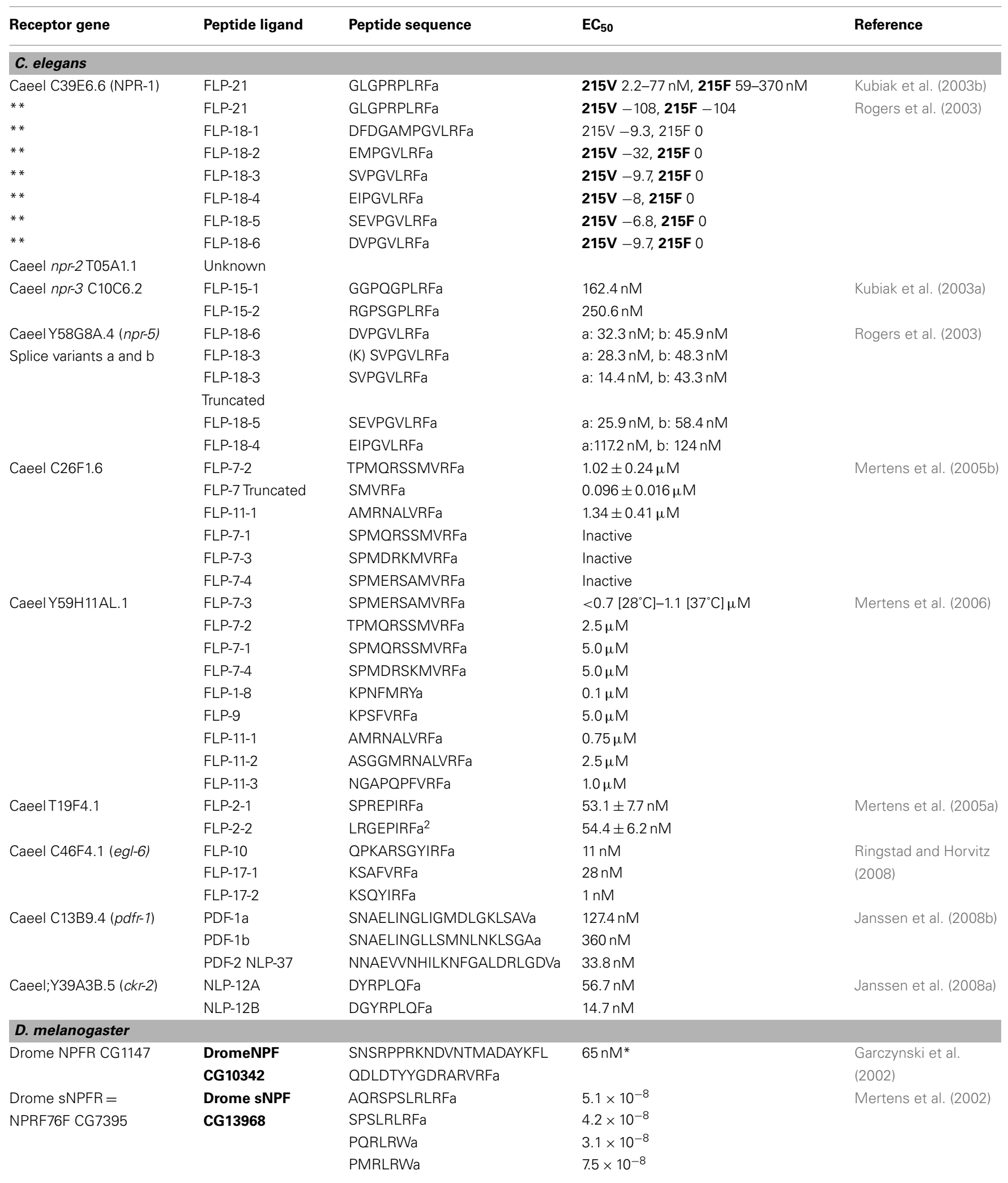


Table 1 | Continued

\begin{tabular}{|c|c|c|c|c|}
\hline Receptor gene & Peptide ligand & Peptide sequence & $\mathrm{EC}_{50}$ & Reference \\
\hline \multirow[t]{7}{*}{ DromeFR CG2114 } & Drome FMRF-1 & DPKQDFMRFa & $2.0 \mathrm{nM}$ & Meeusen et al. \\
\hline & Drome FMRF-2 & TPAEDFMRFa & $2.8 \mathrm{nM}$ & $(2002)$ \\
\hline & Drome FMRF-3 & SDNFMRFa & $1.9 \mathrm{nM}$ & \\
\hline & Drome FMRF-4 & SPKQDFMRFa & $2.5 \mathrm{nM}$ & \\
\hline & Drome FMRF-5 & PDNFMRFa & $1.8 \mathrm{nM}$ & \\
\hline & N. bullata & APPQPSDNFIRFa & $3.5 \mathrm{nM}$ & \\
\hline & N. bullata & pQPSQDFMRFa & $2.0 \mathrm{nM}$ & \\
\hline Drome CG13229 & Unknown & & & \\
\hline \multirow[t]{4}{*}{ Drome PDFR CG1758 } & Drome PDF & NSELINSLLSLPKNMNDAa & $25 \mathrm{nM}$ & Mertens et al. \\
\hline & CG6492 & & & $(2005 c)$ \\
\hline & Drome $\mathrm{DH}_{31}$ & TVDFGLARGYSGTOEAKHRMG & $218.6 \mathrm{nM}$ & \\
\hline & & LAAANFAGGPa & & \\
\hline Drome CCKLR & Drome DSK & FDDY(SO(3)H)GHLRFa & $5.3 \mathrm{nM}$ & Kubiak et al. (2002) \\
\hline
\end{tabular}

* Determined through a competition assay which displaced radioactive peptide from the receptor.

**Values represent alteration of current in response to neuropeptide application in the Xenopus assay.

phenylalanine at position 215 (Caeel $n p r-1215 \mathrm{~F}$ ). Caeel $n p r-1215 \mathrm{~F}$ animals display a "bordering" phenotype as they move rapidly on bacterial food to areas where the food is thickest, and burrow. These animals also show social behavior by interacting with each other to form clumps that can contain hundreds of animals (de Bono and Bargmann, 1998). Caeel NPR-1 acts as an inhibitor of social behavior as Caeel npr-1 loss-of-function (lf) mutants display social behavior. This results in part from Caeel $n p r-1$ (lf) exhibiting enhanced attraction to low levels of the ascaroside pheromone (Macosko et al., 2009). The Caeel npr-1 215 Valine (V) allele is dominant to the Caeel npr-1 215 Phenylalanine (F) allele so that heterozygotes will display solitary behavior. Genetics and targeted expression studies have suggested that NPR-1 acts through neurons AQR, PQR, and URX that are exposed to body fluids (Coates and de Bono, 2002) to suppress aggregation and bordering by inhibiting the expression/activity of two $\alpha / \beta$ soluble guanylate cyclases GCY-35 and GCY-36 that are required to activate a cGMP-gated ion channel (TAX-2/TAX-4) encoded by the tax-2 and tax-4 genes (Cheung et al., 2004; Gray et al., 2005). Social animals may display aggregation and bordering activity as a means of avoiding high $\mathrm{O}_{2}$ levels (hyperoxia) on food. In solitary Caeel NPR-1 215V animals, food suppresses avoidance of hyperoxia by signaling through Caeel NPR-1 via GCY-35/GCY-36 and the TGF$\beta$ homolog DAF-7 (Cheung et al., 2005; Chang et al., 2006). On food, Caeel NPR-1 215V also promotes avoidance of high levels of $\mathrm{CO}_{2}$ whereas the Caeel NPR-1 215F-bearing animal only exhibits a weak avoidance to $\mathrm{CO}_{2}$. Indeed, an increase in $\mathrm{CO}_{2}$ leads to a burst of turning in wild type (N2) worms; however, the Caeel $n p r-1215 F$ strain does not respond. Up or downshifting of $\mathrm{O}_{2}$ has a dramatic effect on turning in Caeel $n p r-1215 F$. The activity of Caeel NPR-1 may thus serve to integrate inputs from $\mathrm{O}_{2}$ - and $\mathrm{CO}_{2}$-sensing pathways and generate an appropriate response with respect to availability of food (Bretscher et al., 2008; Chang and Bargmann, 2008; Hallem and Sternberg, 2008). The $\mathrm{O}_{2}$ and $\mathrm{CO}_{2}$ sensing pathways may control which peptides become involved in regulating Caeel NPR-1. A globin-like gene $(g l b-5)$ appears to cooperate with Caeel npr-1 to mediate responses to $\mathrm{O}_{2}$ and $\mathrm{CO}_{2}$ concentrations. Expression of the globin-like gene ( $g l b-5)$ in animals with a $l f$ allele of Caeel $n p r-1$ showed suppressed aggregation behavior (McGrath et al., 2009).

Caeel NPR-1 has recently been shown to play a role in innate immunity, with Caeel npr-1(lf) animals showing an increased susceptibility to infection by the bacteria Pseudomonas aeruginosa. A similar initial signaling pathway may be used since one of the soluble guanylate cyclases (GCY-35) expressed in AQR, PQR, and URX neurons, and the cGMP-gated ion channel TAX-2/TAX-4 are required (Styer et al., 2008). Caeel $n p r-1$ has been implicated in hyperoxia avoidance in the presence of an exopolysaccharide matrix characteristic of mucoid bacteria. OSM-9 is part of the TRP Vanilloid (TRPV)-like ion channel that is within the ASH and ADL nociceptive neurons (Kapfhamer et al., 2008). The TRPV-like channel mutant (osm-9) mutant exhibited mucoid bacterial avoidance as a consequence of the lack of induction of the Caeel NPR-1 pathway. Worms that lack the TRPV-like channel and guanylate cyclase ( $g c y$-35) showed restored Caeel NPR-1-dependent oxygen sensitivity and absence of pathogen avoidance exhibited by TRPV (osm-9) mutant (Reddy et al., 2011).

The TRPV-like channel appears to work with Caeel NPR1 in several instances of behavioral adaptation/acute tolerance. For example, following exposure of wild type C. elegans to ethanol, intoxication can occur which is assayed by hyperexcitation followed by inhibition of locomotor activity and egg laying. Decreased intoxication as a result of acute tolerance is observed in Caeel NPR-1 215F animals which show a dramatic recovery to ethanol exposure relative to Caeel NPR-1 215V animals. Ethanol-induced clumping of animals was suppressed by the loss of the cGMP-gated ion channel (tax-4) and the TRPV-like channel (osm-9; de Bono et al., 2002). Caeel npr-1 expression in RMG interneurons acts synergistically with TRPV-like channel (osm-9) in parallel pathways to regulate aversive behaviors at high temperature with $n p r-1(l f)$ animals show an increased threshold for heat avoidance (Glauser et al., 2011). 
The initial study to de-orphan Caeel NPR-1 used expression of Caeel $n p r-1$ in a mammalian (CHO) cell line screened with 200 synthetic invertebrate peptide sequences. A single Ascaris suum neuropeptide AF9 (Cowden and Stretton, 1995) was identified as an activating ligand. AF9 is a FMRFamide-related peptide (FaRP) unrelated in sequence to NPY. This peptide sequence has been found in the C. elegans genome and is known as FMRFamidelike peptide-21 (FLP-21; Kubiak et al., 2003b). FLP-21 activation of Caeel NPR-1 results in inhibitory signaling through Gi/Go proteins and inhibition of cAMP production. In GTP $\gamma \mathrm{S}$ binding assays, FLP-21 displayed higher activity with Caeel NPR-1 215V in comparison to Caeel NPR-1 215F (Kubiak et al., 2003b; Table 1). Higher FLP-21 activation of Caeel NPR-1 215V was also noted when the receptor was expressed in Xenopus oocytes and assayed for GIRK channel activation (Rogers et al., 2003; Table 1). This is consistent with the observation that social behavior is repressed in Caeel NPR-1 215V. In the Xenopus assay, in addition to FLP-21, six unique FaRPs encoded by $f l p-18$ were found to activate Caeel NPR-1 215 V but not Caeel NPR-1 215F (Table 1). Using a different assay system in which Caeel NPR-1 isoforms were expressed in the C. elegans pharynx, both isoforms were activated by the sole FLP-21 peptide and all FLP-18 peptides and signaling may occur through $\mathrm{G} \alpha_{\mathrm{q}}$ (Rogers et al., 2003). The expression patterns of $\mathrm{flp}$ 18 and $f l p-21$ have limited overlap. $f l p-18$ is expressed in neurons AVA, AIY, and RIG, motor neurons RIM and pharyngeal neurons M2 and M3. flp-21 is expressed in sensory neurons ADL, ASE, and ASH, motor neuron MRA and pharyngeal neurons MC. M2 and M4. Deletion of $f l p-21$ has a limited effect on increasing aggregation and bordering in Caeel npr-1215V animals but does enhance aggregation in Caeel npr-1 215F animals (Rogers et al., 2003). This supports a role for FLP-18 peptides acting in conjunction with FLP-21 to regulate behavior. However, this is not always the case as FLP-21 does not appear to act in acute ethanol tolerance, suggesting that FLP-18 may be the active ligand. FLP-21 may act solely with Caeel NPR-1 in adaptation to heat avoidance (Glauser et al., 2011).

C53C7.1 is another C. elegans receptor related to the Drosophila neuropeptide F-like receptor. Two isoforms of C53C7.1 are generated by alternative splicing. A single patent report identifies a different FMRFamide-like peptide encoded by the $f l p-3$ gene as the ligand for C53C7 (Lowery et al., 2003).

\section{SHORT NPF AND sNPF RECEPTORS}

The D. melanogaster gene for short NPF (sNPF) encodes a precursor polypeptide that, upon processing, would release two Cterminal RLRFamides (sNPF-1, sNPF-2) and two RLRWamides (sNPF3, sNPF4; Hewes and Taghert, 2001; Vanden Broeck, 2001). Several thousand neurons in the CNS of D. melanogaster express sNPFs suggesting an array of potential functions for these neuropeptides (Nassel et al., 2008). A single neuropeptide GPCR (NPRF76F, CG7395, sNPRF1) is activated by all four sNPFs (Mertens et al., 2002; Table 1). Many sNPF-expressing neurons also co-express classic neurotransmitters suggesting that SNPF could act as a co-transmitter or neuromodulator (Nassel et al., 2008). sNPFs are also produced in the hypocerebral ganglion and in the anterior and middle midgut of D. melanogaster although the function of SNPF at these sites is unknown (Veenstra et al.,
2008). In D. melanogaster, sNPF and sNPFR1 regulate body growth and metabolism by activating extracellular signal-related kinases (ERK) that mediate insulin-like peptide signaling (Lee et al., 2004). This response appears to show evolutionary conservation as mammalian NPY also mediates growth, metabolism, and lifespan through ERK-mediated insulin signaling. Olfactory receptor neurons also express sNPF (Carlsson et al., 2010) and this expression is responsible for starvation-dependent enhancement of food searching behavior. Starvation results in an insulin signal that functions via the phosphoinositide 3-kinase pathway to upregulate sNPFR1 expression in odorant receptor neurons which in turn sensitizes select sensory neurons to promote food search behavior (Root et al., 2011).

In C. elegans, the sequence of NPR-2 (T05A1.1) shares $26 \%$ amino acid sequence identity with the D. melanogaster SNPFR1. Three isoforms of NPR-2, one of 430 aa and two of 387 aa that differ at their amino-terminus, could potentially be generated by alternative splicing. RNAi experiments have demonstrated that knockdown of NPR-2 expression leads to a reduction in locomotion (Keating et al., 2003). Reduction in NPR-2 expression is also associated with an increase in accumulation of intestinal lipid (Cohen et al., 2009). The endogenous ligand is unknown. FLP18 and FLP-21 were tested in the Xenopus oocyte assay and were unable to activate NPR-2 (Cohen et al., 2009).

Caenorhabditis elegans npr-3 (C10C6.2) is currently thought to specify only one GPCR of 376 aa that is expressed in the nerve cord and in excitatory and inhibitory motorneurons in the region of the nerve cord. The NPR-3 sequence, like NPR-2 is most related to the D. melanogaster sNPFR1 sharing $30 \%$ amino acid sequence identity. In C. elegans, the functions of this GPCR are still being established. In one RNAi screen, a knockdown of NPR-3 led to abnormal locomotion, with animals exhibiting sluggish behavior and a flat locomotory path as body bends were reduced (Keating et al., 2003). A second RNAi screen found that reduction of NPR-3 in a lin-35 background (loss of lin-35 results in enhanced RNAi) led to reduced brood size and protruding vulvas (Ceron et al., 2007). Neuropeptides specified by $f l p-15$ appeared to be the only peptides that could activate NPR-3 in a GTP $\gamma S$ assay with membranes prepared from $n p r-3$ transiently transfected $\mathrm{CHO}$ cells. In this assay, FLP-15-2 was a more potent activator than FLP-15-1 (Table 1). This interaction appears to be specific since a peptide such as FLP-21 (Table 1), which shares the carboxyl-terminal GPLRFamide, was inactive. NPR-3 appears to require a distinct conformation as activity was only observed when transiently NPR3 transfected cells were incubated at $28^{\circ} \mathrm{C}$. Membranes prepared from cells incubated at $37^{\circ} \mathrm{C}$ were inactive. Attempts to make a stably transformed NPR-3 cell line with CHO, HEK293, or COS7 cells were unsuccessful and resulted in cell death. In a transient expression assay; NPR-3 appears to activate via pertussis toxinsensitive Gi/Go coupled signaling pathways which suggests that NPR-3 action is inhibitory (Kubiak et al., 2003a).

A second potential sNPF-like GPCR in C. elegans is Y58G8A.4 (NPR-5). NPR-5 RNA is spliced to generate two receptor isoforms of 397 aa (NPR-5a) and 433 aa (NPR-5b) that differ in sequence at the carboxyl-terminus. NPR-5 is most similar (31\% amino acid sequence identity) to the D. melanogaster receptor CG7395 that encodes a NPF-like GPCR; that binds sNPF (Mertens et al., 2002). 
Both isoforms of NPR-5 were assayed for activation with 150 synthetic peptides in a transient expression system in $\mathrm{CHO}$ cells. The most potent activators in a $\mathrm{Ca}^{2+}$ mobilization assay were peptides derived from the $f l p-18$ gene. FLP-18 peptides showed activation with $\mathrm{EC}_{50}$ values in the $\mathrm{nM}$ range, with most having similar potencies using either NPR-5a or b (Table 1). The least active peptide was the longest FLP-18-1 which is also the least active when assayed with the NPF-like receptor NPR-1 (Rogers et al., 2003). FLP-18-1 has been isolated as a processed peptide with the first three aminoterminal amino acids removed which may result in a more potent form of the peptide (Clynen et al., 2009). The sole FLP-21 peptide, that is the cognate ligand for NPR-1, was found to activate both forms of NPR-5 but with far less potency (Kubiak et al., 2008). This is not surprising since FLP-18 peptides have been shown to activate NPR-1 in oocyte expression assays as well as in a C. elegans pharyngeal expression assay (Rogers et al., 2003). It is unclear whether the FLP-18 and FLP-21 peptides work together. The two isoforms of NPR-5 may activate multiple signal transduction pathways as contributions from $\mathrm{G}_{\mathrm{q}}, \mathrm{G}_{\mathrm{s}}$, and $\mathrm{G}_{\mathrm{i}}$ were observed (Kubiak et al., 2008). Deletion mutants of $f l p-18$ display no measurable phenotype.

\section{FMRFAMIDES AND FMRFAMIDE-RELATED RECEPTORS}

In vertebrate systems, neuropeptides with C-terminal sequence FMRFamide and FaRPs function in regulation of muscle contraction, feeding behavior, and learning and memory (Panula et al., 1996).

In D. melanogaster, FMRFamides are expressed from a single gene that encodes a precursor specifying 8 FMRFamide peptides. Five copies of the peptide Drome FMRF-1 would be released from the precursor (Table 1; Schneider et al., 1993). In vitro assays have established that FMRFamides function as modulators of muscle contraction, including in larval heart muscle; crop, foregut, and muscle of the body wall (Nichols et al., 2002; Nichols, 2003). The D. melanogaster FMRFamide GPCR (CG2114; Drome FR) is expressed in most larval and adult tissues. Drome FR was de-orphaned in two independent studies. In an aequorin bioluminescence assay, Drome FMRFamides 1-5 (numbered as unique FMRFamide-terminating peptide sequences from amino to the carboxyl-terminus of the precursor) were found to elicit a calcium response in a dose-dependent manner in $\mathrm{CHO}$ expressing (Table 1). Neobellieria bullata FMRFamide peptides were found to be active with the Drome FR with comparable potencies to native Drome FMRFamides (Table 1; Meeusen et al., 2002). Drome FMRFamide-5 was the most potent ligand in both studies (Cazzamali and Grimmelikhuijzen, 2002; Meeusen et al., 2002). Both studies found that the Drome FR can be activated by nonFMRFamide peptides such as Drome sNPF-1 and Drome myosuppressin; however, these peptides require much higher concentrations to elicit a response. Despite the high concentration required, FMRFamides were recently shown to act post-synaptically, inducing slow larval body wall contractions and increased tonus of the body wall muscles. The latter action of Drome FMRFamide requires activation of Drome FR and the Drome myosuppressin GPCR as well as an influx of calcium through L-type calcium channels (Klose et al., 2010). A role in reproduction had been suggested for Drome FR (Meeusen et al., 2002) as it is related in sequence to a sex peptide receptor (CG16752); however, the Drome FR could not replace the sex peptide receptor in in vitro expression assays (Yapici et al., 2008). Drome CG2114 shares 16-20\% amino acid identity with C. elegans GPCRs F21C10.9 and C26F1.6. Following knockdown of the expression of the $C$. elegans receptor C26F1.6 by RNAi, a hyperactive egg laying phenotype is observed suggesting that this GPCR functions in control of egg production (Keating et al., 2003). Using expression of Caeel C26F1.6 in mammalian cells, only two neuropeptide sequences elicited a dose-dependent response Peptide FLP-7-2 which is found as two copies within the $f l p-7$ gene-encoded precursor was the most active followed by FLP-11-1 which is one of four peptides specified by the $f l p-11$ gene. Related peptides FLP-7-1, FLP-7-3, and FLP-7-4 processed from the FLP-7 precursor were inactive (Mertens et al., 2004, 2005b; Table 1). The FLP-7-2 peptide is likely cleaved at the arginine at the fifth position from the amino-terminus, as truncating the peptide to the terminal 5 amino acids was more active in receptor activation than the predicted full-length peptide (Mertens et al., 2005b). If processing does occur, all peptides from the FLP-7 precursor could be active peptides for receptor Caeel $\mathrm{C} 26 \mathrm{~F} 1.6$. Alternatively, the unique amino-terminal sequences may be required for targeting.

Caeel Y59H11AL.1 is a FaRP receptor that is related to the invertebrate tachykinin/mammalian neurokinin family of receptors. Caeel Y59H11AL.1 is most closely related to the Drosophila NPYlike receptor (CG5811, DromeNepYr) which is a tachykinin family member. Drome NepYr has not been assigned a functional role. However, the Caeel Y59H11AL.1 receptor appears to play a role in growth and reproduction as knockdown of Caeel Y59H11AL.1 gene expression results in small animals with a reduced brood size (Ceron et al., 2007). Expression of the Caeel Y59H11AL.1 gene results in two potential RNA splice variants that lead to two receptors of 427 aa and 434 aa. The two receptors differ by alteration of peptide sequence at the carboxyl-terminal region of the receptor. Of 68 neuropeptides tested against Caeel Y59H11AL.1 expressed in mammalian cells, the Caeel $f l p-7$ gene-encoded peptide FLP7-3 was the most potent peptide (Table 1; Mertens et al., 2006). Three other peptides processed from the Caeel FLP-7 precursor, FLP-7-1, FLP-7-2, and FLP-7-4 were less active. Peptide FLP-7-4 appears to be the only Caeel FLP-7 precursor-derived peptide that uniquely activates Caeel Y59H11AL.1, as the others activate Caeel C26F1.6 as well. This result is surprising since the two receptors share limited sequence identity. Other peptides that showed weak activation of Caeel Y59H11AL.1 were Caeel FLP-1-8, FLP-9, and FLP-11-1-3 (Table 1; Mertens et al., 2006). Activation by multiple related peptides suggests a functional redundancy in peptide binding or possibly a less selective requirement of the receptor to respond to a variety of signals.

Another FaRP receptor in C. elegans is T19F4.1. RNA splice variants give rise to two receptors of 402 aa (Caeel T19F4.1a) and 432 aa (Caeel T19F4.1b). The difference between the receptors resides with the intracellular carboxy-terminus. After transient expression of each receptor in mammalian cells, two peptides, FLP-2-1 and FLP-2-2 derived from the Caeel $f l p-2$ gene precursor were found to activate in a dose-dependent manner either Caeel T19F4.1a or Caeel T19F4.1b (Table 1). A stable transformed mammalian cell line expressing Caeel T19F4.1b showed far less 
activation with FLP-2-1 and was less responsive when challenged with FLP-2-2 (Mertens et al., 2005a). The reasons for this are unclear. In a genome-wide RNAi screen, knockdown of the Caeel $f l p-2$ gene resulted in lethality in the embryo or larval stages or resulted in postembryonic growth defects (Simmer et al., 2003). No visible phenotypes have been identified in a Caeel FLP-2 receptor knockdown that would affect both splice variants.

Caeel C46F4.1 GPCR was found to be involved in an egg layingdefective phenotype (egl) in C. elegans. The most related receptor in D. melanogaster is Drome CG13229; however, no ligand or function has been ascribed to this unnamed fly receptor. Flyatlas lists low expression in the D. melanogaster nervous system. Caeel C46F4.1 is equivalent to egl-6 (Ringstad and Horvitz, 2008) and two receptor isoforms that differ at the amino-terminus are produced by alternative splicing and alternate start sites. Caeel egl-6 is predominately expressed in HSN motor neurons that innervate vulval muscles and glia-like cells located in the head region. Weaker expression was also noted in DVA tail interneurons. Expression was sometimes seen in lateral interneurons SDQL and SDQR (Ringstad and Horvitz, 2008). A gain-of-function mutant (n592 $g f$ ) that results from a single amino acid change, Alanine 135 to Threonine 135, in the third transmembrane domain enhances EGL-6 activity. The result of this receptor activation is an egg laying-defective phenotype. Thus, EGL-6 normally transduces signals that confer inhibitory activity on the HSN motor neurons. This activity is dependent, in part, on $G_{o}$ signaling. Transgenic overexpression of Caeel $f l p$ and other neuropeptide genes in both wild type and animals that carried an egl- 6 deletion suggested that the ligands for EGL- 6 were dependent on Caeel $f l p-10$ and Caeel $f l p-17$ genes. This was further supported by the demonstration that a Caeel $f l p-10$ deletion mutant suppressed the egg laying defect in the gain-of-function mutant and suppression was further enhanced by deletion of the Caeel $f l p-17$ gene. Peptides FLP-10 and two unique peptide sequences FLP-17-1 and 2, proved to be potent activators of EGL-6 when expressed in X. laevis oocytes. A GIRK channel assay, used to monitor expression, demonstrated that all peptides were potent activators, with $\mathrm{EC}_{50}$ values in the $\mathrm{nM}$ range (Table 1). Expression of Caeel $f l p-17$ is confined to anterior BAG sensory neurons and this expression is necessary for EGL-6 function in egg laying. Expression of Caeel $\mathrm{flp}-10$ occurs in numerous neurons ASIL, ASIR, DVB, PVCL, PVCR, PVR as well as in nonneuronal tissues including head mesodermal cells, vulval tissue, uterine cells, and spermathecae. Only non-neuronal expression of Caeel $\mathrm{flp}$-10 appears to be important in EGL-6 action on egg laying (Ringstad and Horvitz, 2008).

\section{PIGMENT DISPERSING FACTOR AND RECEPTOR}

Pigment dispersing hormone is a light adapting hormone originally identified as responsible for daily rhythms of color change in Crustacea (Meelkop et al., 2011). Similar peptides known as pigment dispersing factors (PDFs) have been identified in arthropods and they are required for normal circadian control of locomotion. In D. melanogaster, the PDF receptor (DromePDFR; CG13758) null mutant does not show any apparent morphological defects. Drome PDFR immunostaining revealed that DromePDFR was localized in 13 neurons in each hemisphere of the adult brain, 4 I-LNV neurons, one of the six LNd neurons, seven neurons in the DN1 area, and one neuron in the DN3 area. In a 12-h Light/Dark cycle, the receptor null mutants started morning activity later than wild type and began evening activity earlier than wild type. Placing animals in $24 \mathrm{~h}$ dark conditions for 8 days resulted in a loss of rhythmic activity. This behavior is seen in Drosophila PDF mutants, suggesting that DromePDF and DromePDFR may be part of a pathway that controls rhythmic circadian behavior. DromePDFR can be activated with Drome PDF, pituitary adenylate cyclase activating polypeptide (PACAP), or calcitonin-like peptides (Drome $\mathrm{DH}_{31}$; Mertens et al., 2005c).

A search of the C. elegans database for a PDF receptor (PDFR) ortholog using the Drosophila PDFR (CG13758) as a query sequence (Renn et al., 1999) resulted in the identification of the gene Caeel C13B9.4 as coding for a Caeel PDFR. Transcription and alternate splicing of gene Caeel C13B9.4 mRNA gives rise to six mRNAs (Wormbase). Two mRNAs that differ by variable length of the $5^{\prime}$ untranslated region specifies one of three related receptors. These three receptor isoforms differ at the amino-terminal region of the proteins, generating receptors of 543 aa (Caeel PDFR1a); 536 aa (CaeelPDRF-1b), and 541 aa (Caeel PDRF-1c). Caeel C13B9.4 promoter-driven reporter expression showed that expression of this receptor is extensive. Expression was observed in chemosensory neurons $\mathrm{PHA}$ and $\mathrm{PHB}$, mechanosensory neurons PLM, ALM, FLP, OLQD, and OLQV, the ring motor neuron RMED, the I1 pharyngeal interneuron pair, and a single sensory neuron R3 in the male tail. In non-neuronal tissue, expression was found in 95 body wall muscles and two vulval cells (Janssen et al., 2008b). This localization is similar to the localization of PDF-like neuropeptides which are found in neurons involved in chemosensation, mechanosensation, oxygen sensing, and locomotion (Janssen et al., 2008b). Expression of each of the three receptor isoforms in stably transformed CHO cells demonstrated that only three of 156 synthetic C. elegans peptides were active in a calcium bioluminescence assay. These included Caeel PDF-1a, PDF-1b, and PDF-2 = NLP37 (Table 1). These three peptides were most active with Caeel PDFR-1b but showed reduced activity with Caeel PDFR-1a. Caeel PDFR-1c was inactive in this assay. In a cAMP activation assay in transiently transfected HEK293 cells, all three receptor isoforms were activated by Caeel PDF-1a, Caeel PDF-1b, and Caeel PDF-2, which suggests signaling through $G \alpha_{s}$. In this assay, Caeel-PDFR$1 \mathrm{~b}$ was the most active and responded particularly to Caeel PDF-2. Caeel PDFR-1c was the least active isoform. Cells expressing Caeel PDFR-1 responded to all three peptides in a dose-dependent manner, using the ability to inhibit forskolin-induced cAMP formation, which suggests that Caeel PDFR-1c may participate in coupling with additional $\mathrm{G}$-proteins such as $\mathrm{G} \alpha_{\mathrm{i} / \mathrm{o}}$.

A Caeel $p d f-1$ (lf) results in a decrease in the speed of movement of worms, an increase in the reversal frequency and an increase in the frequency of directional change. The net result is that the distance that animals travel in the forward direction is dramatically reduced. These locomotor defects are not seen in animals in which Caeel $p d f-1$ is over-expressed. In contrast, overexpression of Caeel $p d f-2$ results in a phenotype equivalent to the Caeel $p d f-1$ (lf). Overexpression of Caeel $p d f r-1$ (expressing all 3 isoforms) results in animals that show a dramatic increase in reversal frequency but lack changes in speed of movement or directional change. The current model is that Caeel PDF-1 peptides activate Caeel PDFR-1 to 
stimulate forward movement and/or inhibit backward movement and this effect is counter-balanced by Caeel PDF-2 acting on Caeel PDFR-1 to inhibit forward movement and/or stimulate backward movement (Janssen et al., 2008b). D. melanogaster clock genes have counterparts in C. elegans. Null alleles of $C$. elegans clock genes reduced mRNA levels of Caeel $p d f-1 a, p d f-1 b$, and $p d f-2$ which implicates Caeel PDF-1 and 2 activity as dependent on the clock genes. Caeel $p d f-1$ appears to work independently of Caeel $p d f-2$ as the level of one does not affect the other (Janssen et al., 2009).

\section{CHOLECYSTOKININ AND ITS RECEPTOR}

Cholecystokinin (CK) is known in vertebrates as a regulator of food intake as it functions to stimulate smooth muscle contraction which, in vertebrates, includes intestinal and gall bladder contractions. CK also stimulates the secretion of digestive enzymes such as $\alpha$-amylase (Dufresne et al., 2006). The D. melanogaster CK-like receptor (Drome CCKLR) was identified based on homology to mammalian $\mathrm{CK}$ receptors (CKR) and was found in mammalian expression assays to bind to a sulfated FMRFamide-like peptide, drosulfakinin (Drome DSK). The sulfated form of Drome DSK is necessary to achieve specific interaction with EC50 values in the nM range (Kubiak et al., 2002). Analysis of loss-of-function mutations in either Drome CCKLR or Drome DSK results in neuromuscular junction undergrowth suggesting that both GPCR and ligand are required pre-synaptically to promote neuromuscular junction growth. Genetically, Drome CCKLR and Drome DSK were found to function upstream of Gas which in turn regulates a cAMPdependent protein kinase which then acts on a transcriptional regulatory protein CREB2 which is the primary effector of the pathway (Chen and Ganetzky, 2012). In C. elegans, CaeelY39A3B.5 shares 67\% similarity with mammalian CKR (CCK2R) and 64\% with sulfakinin receptors (DK-R1; Johnsen, 1998; Janssen et al., 2008a). Through computer predicted alternate splicing, Caeel Y39A3B.5 produces four isoforms of 582 aa (Y39A3B.5a), 552 aa (Y39A3B.5b), 471 aa (Y39A3B.5c), and 617 aa (Y39A3B.5; Wormbase). Additional isoforms may exist as two further isoforms were identified as a result of sequencing DNA generated experimentally by reverse-transcriptase PCR. Both contained the first eight exons of isoform $\mathrm{c}$ but then differed, as one contained the last two exons of isoform b (Y39A3B.5c/b = Caeel CKR-2a) and the second the last four exons of isoform $d$ (Y39A3B.5c/d = Caeel CKR-2b). These two receptors were de-orphaned by transient expression in $\mathrm{CHO}$ cell lines, using a calcium bioluminescence assay. Caeel NLP-12a and Caeel NLP-12b were the only peptides tested that activated Caeel CKRs in a dose-dependent manner (Table 1). The most potent ligand for Caeel CKR-2a was Caeel NLP-12b whereas NLP-12a showed a higher potency than NLP$12 \mathrm{~b}$ with CKR-2b. NLP-12 is localized to a tail interneuron DVA and to processes from DVA that extend around the nerve ring. Expression was also observed in all six coelomocytes. In common with vertebrates, Caeel NLP-12 can regulate digestion since Caeel $c k r-2(l f)$ have decreased intestinal $\alpha$-amylase and both Caeel $c k r$-2(lf) and Caeel $n l p-12$ (lf) animals gain fat even though there is no difference in pharyngeal pumping rate or defecation rate. Caeel $c k r-2$ and its ligand, Caeel $n l p-12$, may also be involved in a mechanosensory feedback loop that couples muscle contraction to changes in pre-synaptic ACh release (Hu et al., 2011).

\section{ALLATOSTATIN-LIKE PEPTIDES AND RECEPTORS}

Mammalian galanin is a neuropeptide that regulates numerous physiological processes including neurotransmission, nociception, feeding and metabolism, energy, and osmotic homeostasis as well as learning and memory (Lang et al., 2007). Insect allatostatins (ASTs) have a carboxyl-terminal sequence Y (Xaa) FGL-amide and have multiple functions that include inhibition of juvenile hormone biosynthesis (Bendena et al., 1999; Tobe and Bendena, 2012) inhibition of muscle contraction, regulation of digestive enzymes, and neuromodulation (Tobe and Bendena, 2012). In Drosophila Drome FGL-amide ASTs do not inhibit juvenile hormone biosynthesis. RNAi reduction in Drome AST or Drome ASTR transcripts results in reduced locomotory behavior in the presence of food. Locomotion is normal in the absence of food. Reduction in Drome AST and Drome ASTR is correlated with decreased for transcript levels which encodes cGMP-dependent protein kinase. A reduction in the for transcript is known to be associated with a naturally occurring allelic variation that creates a sitter phenotype in contrast to the rover phenotype which is caused by a for allele associated with increased for activity (Wang et al., 2012). In C. elegans the gene Caeel npr-9 expresses a single GPCR isoform of 444 aa that shares 33 and $37 \%$ amino acid sequence identity with mammalian galanin receptor 2 and the Drome allatostatin receptor (Drome ASTR), respectively. Promoter-driven reporter expression suggests that Caeel $n p r-9$ is transcribed exclusively in interneuron AIB. Caeel NPR-9 appears to function as an inhibitor of local search behavior in the presence of a food stimulus. In the absence of food. Caeel npr-9 (lf) mutants display locomotory activity that is identical to wild type animals. Caeel $n p r-9$ (lf) mutants behave as if AIB is stimulated (increased pivoting and local search). Caeel $n p r-9(l f)$ animals also accumulate fat at an accelerated rate relative to wild type and thus again resemble galanin/allatostatin neuropeptides that affect metabolism. This contrasts with Caeel npr- $9(g f)$ animals (overexpression of Caeel NPR-9) which display enhanced forward locomotion that mimic the phenotype displayed by AIB laser ablation or a mutation in the glutamate receptor-1 (Bendena et al., 2008). Caeel $n p r-9(g f)$ animals travel long distances off food, presumably as a result of overriding dopamine, and glutamate signals that evoke "area restricted search" behavior in wild type animals. Area restricted search is characterized by frequent reversals and sharp omega-turns that function to maximize the time spent on an abundant food source (Hills et al., 2004). The ligands for Caeel NPR-9 have not yet been identified. Two genes, Caeel $n l p-5$ and Caeel $n l p-6$, specify peptides that resemble ASTs. Caeel $n l p-5$ and Caeel $n l p-6$ specify peptides with carboxyl-terminal MGLamide and MGFamide, respectively. Caeel $n l p-6$ encodes a peptide with carboxy-terminal FGFamide. A mutation in Caeel $n l p-5$ has been reported to result in animals with altered locomotory behavior on food (Bargmann, Wormbase), which appears to be similar to behaviors exhibited by Caeel npr-9(lf) animals.

\section{PERSPECTIVES}

High throughput neuropeptide projects are expected to facilitate de-orphanization of all of the predicted D. melanogaster and $C$. elegans neuropeptide receptors. These neuropeptides and their receptors will serve as starting points to understand the functional 
significance of these signaling events. Both organisms serve as genetic models not only for matching GPCRs with their respective neuropeptide ligand but offer a means of uncovering signal transduction pathways that lead to novel behaviors. Genetic modifier screens and genome-wide RNAi screens will certainly identify many of the neuropeptide signaling components. C. elegans transgenic studies will allow the manipulation of neuropeptide receptor signaling at the level of a single cell or tissue within an entire

\section{REFERENCES}

Barak, L. S., Ferguson, S. S. G., Zhang, J., and Caron, M. G. (1997). A betaarrestin green fluorescent protein biosensor for detecting $\mathrm{G}$ proteincoupled receptor activation. J. Biol. Chem. 272, 27497-27500.

Bargmann, C. I. (1998). Neurobiology of the Caenorhabditis elegans genome. Science 282, 2028-2033.

Bargmann, C. I. (2006). Chemosensation in C. elegans. WormBook 1-29. Available at: http://www.wormbook.org

Bendena, W. G., Boudreau, J. R., Papanicolaou, T., Maltby, M., Tobe, S. S., and Chin-Sang, I. D. (2008). A Caenorhabditis elegans allatostatin/galanin-like receptor NPR-9 inhibits local search behavior in response to feeding cues. Proc. Natl. Acad. Sci. U.S.A. 105, 1339-1342.

Bendena, W. G., Donly, B. C., and Tobe, S. S. (1999). Allatostatins: a growing family of neuropeptides with structural and functional diversity. Ann. N. Y. Acad. Sci. 897, 311-329.

Bretscher, A. J., Busch, K. E., and de Bono, M. (2008). A carbon dioxide avoidance behavior is integrated with responses to ambient oxygen and food in Caenorhabditis elegans. Proc. Natl. Acad. Sci. U.S.A. 105, 8044-8049.

Brown, M. R., Crim, J. W., Arata, R. C., Cai, H. N., Chun, C., and Shen, P. (1999). Identification of a Drosophila brain-gut peptide related to the neuropeptide Y family. Peptides 20, 1035-1042.

Browning, K. N., and Travagli, R. A. (2003). Neuropeptide Y and peptide YY inhibit excitatory synaptic transmission in the rat dorsal motor nucleus of the vagus. J. Physiol. (Lond.) 549, 775-785.

Campesan, S., Green, E. W., Breda, C., Sathyasaikumar, K. V., Muchowski, P. J., Schwarcz, R., Kyriacou, C. P., and Giorgini, F. (2011). The kynurenine pathway modulates neurodegeneration in a Drosophila model of Huntington's disease. Curr. Biol. 21, 961-966.

Carlsson, M. A., Diesner, M., Schachtner, J., and Nassel, D. R. (2010). Multiple neuropeptides in the
Drosophila antennal lobe suggest complex modulatory circuits. J. Comp. Neurol. 518, 3359-3380.

Cazzamali, G., and Grimmelikhuijzen, C. J. (2002). Molecular cloning and functional expression of the first insect FMRFamide receptor. Proc. Natl. Acad. Sci. U.S.A. 99, 12073-12078.

Ceron, J., Rual, J. F., Chandra, A., Dupuy, D., Vidal, M., and van den Heuvel, S. (2007). Large-scale RNAi screens identify novel genes that interact with the $C$. elegans retinoblastoma pathway as well as splicingrelated components with synMuv doi:10.1186/1471-213X-7-30

Chakraborty, R., Vepuri, V., Mhatre, S. D., Paddock, B. E., Miller, S., Michelson, S. J., Delvadia, R., Desai, A., Vinokur, M., Melicharek, D. J., Utreja, S., Khandelwal, P., Ansaloni, S., Goldstein, L. E., Moir, R. D., Lee, J. C., Tabb, L. P., Saunders, A. J., and Marenda, D. R. (2011). Characterization of a Drosophila Alzheimer's disease model: pharmacological rescue of cognitive defects. PLOS ONE 6, e20799. doi:10.1371/journal.pone.0020799

Chang, A. J., and Bargmann, C. I. (2008). Hypoxia and the HIF1 transcriptional pathway reorganize a neuronal circuit for oxygendependent behavior in Caenorhabditis elegans. Proc. Natl. Acad. Sci. U.S.A. 105, 7321-7326.

Chang, A. J., Chronis, N., Karow, D. S., Marletta, M. A., and Bargmann, C. I. (2006). A distributed chemosensory circuit for oxygen preference in C. elegans. PLoS Biol. 4, e274. doi:10.1371/journal.pbio.0040274

Chen, X., and Ganetzky, B. (2012). A neuropeptide signaling pathway regulates synaptic growth in Drosophila. J. Cell Biol. 196, 529-543.

Cheung, B. H., Arellano-Carbajal, F., Rybicki, I., and de Bono, M. (2004). Soluble guanylate cyclases act in neurons exposed to the body fluid to promote C. elegans aggregation behavior. Curr. Biol. 14, 1105-1111.

Cheung, B. H., Cohen, M., Rogers, C., Albayram, O., and de Bono, M. (2005). Experience-dependent B activity. BMC Dev. Biol. 7, 30.

organism. As many of these receptors have counterparts in mammals, it will not be surprising to find similar signaling pathways conserved throughout evolution.

\section{ACKNOWLEDGMENTS}

This work was supported by Natural Science and Engineering Research Council of Canada (NSERC) grants to William Bendena and Ian Chin-Sang.

modulation of C. elegans behavior by ambient oxygen. Curr. Biol. 15 905-917.

Clark, J. T., Kalra, P. S., Crowley, W. R., and Kalra, S. P. (1984) Neuropeptide-Y and human pancreatic-polypeptide stimulate feeding behavior in rats. Endocrinology 115, 427-429.

Clynen, E., Husson, S. J., and Schoofs, L. (2009). Identification of new members of the (short) neuropeptide $\mathrm{F}$ family in locusts and Caenorhabditis elegans. Trends Comp. Endocrinol. Neurobiol. 1163, 60-74.

Clynen, E., Reumer, A., Baggerman, G., Mertens, I., and Schoofs, L. (2010). Neuropeptide biology in Drosophila. Adv. Exp. Med. and Biol. 692, 192-210

Coates, J. C., and de Bono, M. (2002). Antagonistic pathways in neurons exposed to body fluid regulate social feeding in Caenorhabditis elegans. Nature 419, 925-929.

Cohen, M., Reale, V., Olofsson, B., Knights, A., Evans, P., and de Bono, M. (2009). Coordinated regulation of foraging and metabolism in C. elegans by RFamide neuropeptide signaling. Cell Metab. 9, 375-385.

Cowden, C., and Stretton, A. O. (1995). Eight novel FMRFamide-like neuropeptides isolated from the nematode Ascaris suum. Peptides 16, 491-500.

de Bono, M., and Bargmann, C. I. (1998). Natural variation in a neuropeptide Y receptor homolog modifies social behavior and food response in C. elegans. Cell 94, 679-689.

de Bono, M., Tobin, D. M., Davis, M. W., Avery, L., and Bargmann, C. I. (2002). Social feeding in Caenorhabditis elegans is induced by neurons that detect aversive stimuli. Nature 419, 899-903.

De Strooper, B., Annaert, W., Cupers, P., Saftig, P., Craessaerts, K., Mumm, J. S., Schroeter, E. H., Schrijvers, V., Wolfe, M. S., Ray, W. J., Goate, A., and Kopan, R. (1999). A presenilin1-dependent gamma-secretase-like protease mediates release of Notch intracellular domain. Nature 398, 518-522.
Dierick, H. A., and Greenspan, R. J. (2007). Serotonin and neuropeptide F have opposite modulatory effects on fly aggression. Nat. Genet. 39, 678-682.

Dufresne, M., Seva, C., and Fourmy, D. (2006). Cholecystokinin and gastrin receptors. Physiol. Rev. 86, 805-847.

Feany, M. B., and Bender, W. W. (2000). A Drosophila model of Parkinson's disease. Nature 404, 394-398.

Fredriksson, R., Lagerström, M. C., Lundin, L., and Schiöth, H. B. (2003). The G-protein-coupled receptors in the human genome form five main families. Phylogenetic analysis, paralogon groups, and fingerprints. Mol. Pharmacol. 63, 1256-1272.

Garczynski, S. F., Brown, M. R., Shen, P., Murray, T. F., and Crim, J. W. (2002). Characterization of a functional neuropeptide $\mathrm{F}$ receptor from Drosophila melanogaster. Peptides 23, 773-780.

Geary, T. G., Marks, N. J., Maule, A. G., Bowman, J. W., Alexander-Bowman, S. J., Day, T. A., Larsen, M. J., Kubiak, T. M., Davis, J. P., and Thompson, D. P. (1999). Pharmacology of FMRFamide-related peptides in helminths. Ann. N. Y. Acad. Sci. 897, 212-227.

Glauser, D. A., Chen, W. C., Agin, R., MacInnis, B. L., Hellman, A. B. Garrity, P. A., Tan, M., and Goodman, M. B. (2011). Heat avoidance is regulated by transient receptor potential (TRP) channels and a neuropeptide signaling pathway in Caenorhabditis elegans. Genetics 188 , 91-U150.

Gray, J. M., Hill, J. J., and Bargmann, C. I. (2005). A circuit for navigation in Caenorhabditis elegans. Proc. Natl. Acad. Sci. U.S.A. 102, 3184-3191.

Hallem, E. A., and Sternberg, P. W. (2008). Acute carbon dioxide avoidance in Caenorhabditis elegans. Proc. Natl. Acad. Sci. U.S.A. 105, 8038-8043.

Harada, Y., Takahashi, T., Kuno, M., Nakayama, K., Masu, Y., and Nakanishi, S. (1987). Expression of two different tachykinin receptors in Xenopus oocytes by exogenous mRNAs. $J$. Neurosci. 7, 3265-3273. 
Hermann, C., Yoshii, T., Dusik, V., and Helfrich-Foerster, C. (2012). Neuropeptide $\mathrm{F}$ immunoreactive clock neurons modify evening locomotor activity and free-running period in Drosophila melanogaster. J. Comp. Neurol. 520, 970-987.

Hewes, R. S., and Taghert, P. H. (2001). Neuropeptides and neuropeptide receptors in the Drosophila melanogaster genome. Genome Res. 11, 1126-1142.

Hills, T., Brockie, P. J., and Maricq, A. V. (2004). Dopamine and glutamate control area-restricted search behavior in Caenorhabditis elegans. J. Neurosci. 24, 1217-1225.

Hu, Z., Pym, E. C. G., Babu, K., Murray, A. B. V., and Kaplan, J. M. (2011). A neuropeptide-mediated stretch response links muscle contraction to changes in neurotransmitter release. Neuron 71, 92-102.

Husson, S. J., Mertens, I., Janssen, T., Lindemans, M., and Schoofs, L. (2007). Neuropeptidergic signaling in the nematode Caenorhabditis elegans. Prog. Neurobiol. 82, 33-55.

Janssen, T., Husson, S. J., Meelkop, E., Temmerman, L., Lindemans, M., Verstraelen, K., Rademakers, S., Mertens, I., Nitabach, M., Jansen, G., and Schoofs, L. (2009). Discovery and characterization of a conserved pigment dispersing factor-like neuropeptide pathway in Caenorhabditis elegans. J. Neurochem. 111, 228-241.

Janssen, T., Meelkop, E., Lindemans, M., Verstraelen, K., Husson, S. J., Temmerman, L., Nachman, R. J., and Schoofs, L. (2008a). Discovery of a cholecystokinin-gastrinlike signaling system in nematodes. Endocrinology 149, 2826-2839.

Janssen, T., Husson, S. J., Lindemans, M., Mertens, I., Rademakers, S., Ver Donck, K., Geysen, J., Jansen, G., and Schoofs, L. (2008b). Functional characterization of three $G$ proteincoupled receptors for pigment dispersing factors in Caenorhabditis elegans. J. Biol. Chem. 283, 15241-15249.

Johnsen, A. H. (1998). Phylogeny of the cholecystokinin/gastrin family. Front. Neuroendocrinol. 19, 73-99.

Johnson, E. C., Bohn, L. M., Barak, L. S., Birse, R. T., Nassel, D. R., Caron, M. G., and Taghert, P. H. (2003). Identification of Drosophila neuropeptide receptors by $G$ protein-coupled receptorsbeta-arrestin2 interactions. J. Biol. Chem. 278, 52172-52178.

Kalra, S. P. (1997). Appetite and body weight regulation: is it all in the brain? Neuron 19, 227-230.
Kapfhamer, D., Bettinger, J. C., Davies, A. G., Eastman, C. L., Smail, E. A., Heberlein, U., and McIntire, S. L. (2008). Loss of RAB-3/A in Caenorhabditis elegans and the mouse affects behavioral response to ethanol. Genes Brain Behav. 7, 669-676.

Keating, C. D., Kriek, N., Daniels, M., Ashcroft, N. R., Hopper, N. A., Siney, E. J., Holden-Dye, L., and Burke, J. F. (2003). Whole-genome analysis of $60 \mathrm{G}$ protein-coupled receptors in Caenorhabditis elegans by gene knockout with RNAi. Curr. Biol. 13, 1715-1720.

Klapstein, G. J., and Colmers, W. F. (1993). On the sites of presynaptic inhibition by neuropeptide-Y in rat hippocampus in vitro. Hippocampus 3, 103-112.

Klose, M. K., Dason, J. S., Atwood, H. L., Boulianne, G. L., and Mercier, A. J. (2010). Peptideinduced modulation of synaptic transmission and escape response in Drosophila requires two G-proteincoupled receptors. J. Neurosci. 30, 14724-14734.

Krashes, M. J., DasGupta, S., Vreede, A., White, B., Armstrong, J. D., and Waddell, S. (2009). A neural circuit mechanism integrating motivational state with memory expression in Drosophila. Cell 139, 416-427.

Krishnan, A., Almén, M. S., Fredriksson, R., and Schiöth, H. B. (2012). The origin of GPCRs: identification of mammalian like Rhodopsin, Adhesion, Glutamate and Frizzled GPCRs in fungi. PLoS ONE e29817. doi:10.1371/journal.pone.0029817

Kubiak, T. M., Larsen, M. J., Bowman, J. W., Geary, T. G., and Lowery, D. E. (2008). FMRFamidelike peptides encoded on the flp18 precursor gene activate two isoforms of the orphan Caenorhabditis elegans G-protein-coupled receptor Y58G8A.4 heterologously expressed in mammalian cells. Biopolymers 90 , 339-348.

Kubiak, T. M., Larsen, M. J., Burton, K. J., Bannow, C. A., Martin, R. A., Zantello, M. R., and Lowery, D. E. (2002). Cloning and functional expression of the first Drosophila melanogaster sulfakinin receptor DSK-R1. Biochem. Biophys. Res. Commun. 291, 313-320.

Kubiak, T. M., Larsen, M. J., Zantello, M. R., Bowman, J. W., Nulf, S. C. and Lowery, D. E. (2003a). Functional annotation of the putative orphan Caenorhabditis elegans Gprotein-coupled receptor C10C6.2 as a FLP15 peptide receptor. J. Biol. Chem. 278, 42115-42120.
Kubiak, T. M., Larsen, M. J., Nulf, S. C. Zantello, M. R., Burton, K. J., Bowman, J. W., Modric, T., and Lowery, D. E. (2003b). Differential activation of "social" and "solitary" variants of the Caenorhabditis elegans $\mathrm{G}$ protein-coupled receptor NPR-1 by its cognate ligand AF9. J. Biol. Chem. 278, 33724-33729.

Lang, R., Gundlach, A. L., and Kofler, B. (2007). The galanin peptide family: receptor pharmacology, pleiotropic biological actions, and implications in health and disease. Pharmacol. Ther. 115, 177-207.

Larsen, M. J., Burton, K. J., Zantello, M. R., Smith, V. G., Lowery, D. L., and Kubiak, T. M. (2001). Type A allatostatins from Drosophila melanogaster and Diplotera puncata activate two Drosophila allatostatin receptors, DAR-1 and DAR-2, expressed in CHO cells. Biochem. Biophys. Res. Commun. 286, 895-901.

Lee, G., Bahn, J. H., and Park, J. H. (2006). Sex- and clock-controlled expression of the neuropeptide $\mathrm{F}$ gene in Drosophila. Proc. Natl. Acad. Sci. U.S.A. 103, 12580-12585.

Lee, K. S., You, K. H., Choo, J. K., Han, Y. M., and Yu, K. (2004). Drosophila short neuropeptide $\mathrm{F}$ regulates food intake and body size. J. Biol. Chem. 279, 50781-50789.

Li, C., and Kim, K. (2008). Neuropeptides. WormBook 1-36. Available at: http://www.wormbook.org

Lowery, D. E., Geary, T. G., Kubiak, T. M., and Larsen, M. J. (2003). $G$ Protein-Coupled Receptors and Modulators Thereof. US Patent No. 6,632,621

Macosko, E. Z., Pokala, N., Feinberg, E. H., Chalasani, S. H., Butcher, R. A., Clardy, J., and Bargmann, C. I. (2009). A hub-and-spoke circuit drives pheromone attraction and social behaviour in C-elegans. Nature 458 1171-U110.

McGrath, P. T., Rockman, M. V., Zimmer, M., Jang, H., Macosko, E. Z., Kruglyak, L., and Bargmann, C. I. (2009). Quantitative mapping of a digenic behavioral trait implicates globin variation in C. elegans sensory behaviors. Neuron 61, 692-699.

Meelkop, E., Temmerman, L., Schoofs, L., and Janssen, T. (2011). Signalling through pigment dispersing hormone-like peptides in invertebrates. Prog. Neurobiol. 93, 125-147.

Meeusen, T., Mertens, I., Clynen, E., Baggerman, G., Nichols, R., Nachman, R. J., Huybrechts, R., De Loof, A., and Schoofs, L. (2002). Identification in Drosophila melanogaster of the invertebrate $G$ protein-coupled
FMRFamide receptor. Proc. Natl. Acad. Sci. U.S.A. 99, 15363-15368.

Mertens, I., Clinckspoor, I., Janssen, T., Nachman, R., and Schoofs, L. (2006). FMRFamide related peptide ligands activate the Caenorhabditis elegans orphan GPCR Y59H11AL.1. Peptides 27, 1291-1296.

Mertens, I., Meeusen, T., Huybrechts, R., De Loof, A., and Schoofs, L. (2002). Characterization of the short neuropeptide $\mathrm{F}$ receptor from Drosophila melanogaster. Biochem. Biophys. Res. Commun. 297, 1140-1148.

Mertens, I., Meeusen, T., Janssen, T., Nachman, R., and Schoofs, L. (2005a). Molecular characterization of two $G$ protein-coupled receptor splice variants as FLP2 receptors in Caenorhabditis elegans. Biochem. Biophys. Res. Commun. 330, 967-974.

Mertens, I., Vandingenen, A., Clynen, E., Nachman, R. J., De Loof, A., and Schoofs, L. (2005b). Characterization of an RFamide-related peptide orphan GPCR in C. elegans. Ann. N. Y. Acad. Sci. 1040, 410-412.

Mertens, I., Vandingenen, A., Johnson, E. C., Shafer, O. T., Li, W., Trigg, J. S., De Loof, A., Schoofs, L., and Taghert, P. H. (2005c). PDF receptor signaling in Drosophila contributes to both circadian and geotactic behaviors. Neuron 48, 213-219.

Mertens, I., Vandingenen, A., Meeusen, T., Janssen, T., Luyten, W., Nachman, R. J., De Loof, A., and Schoofs, L. (2004). Functional characterization of the putative orphan neuropeptide G-protein coupled receptor C26F1.6 in Caenorhabditis elegans. FEBS Lett. 573, 55-60.

Nakae, J., Biggs, W. H. III, Kitamura, T., Cavenee, W. K., Wright, C. V., Arden, K. C., and Accili, D. (2002). Regulation of insulin action and pancreatic beta-cell function by mutated alleles of the gene encoding forkhead transcription factor Foxol. Nat. Genet. 32, 245-253.

Nassel, D. R., Enell, L. E., Santos, J. G., Wegener, C., and Johard, H. A. D. (2008). A large population of diverse neurons in the Drosophila central nervous system expresses short neuropeptide $\mathrm{F}$, suggesting multiple distributed peptide functions. $B M C$ Neurosci. 9, 90. doi:10.1186/14712202-9-90

Nathoo, A. N., Moeller, R. A., Westlund, B. A., and Hart, A. C. (2001). Identification of neuropeptide-like protein gene families in Caenorhabditis elegans and other species. Proc. Natl. Acad. Sci. U.S.A. 98, 14000-14005. 
Nichols, R. (2003). Signaling pathways and physiological functions of Drosophila melanogaster FMRFamide-related peptides. Annu. Rev. Entomol. 48, 485-503.

Nichols, R., Bendena, W. G., and Tobe, S. S. (2002). Myotropic peptides in Drosophila melanogaster and the genes that encode them. J. Neurogenet. 16, 1-28.

O'Kane, C. J. (2011). Drosophila as a model organism for the study of neuropsychiatric disorders. Mol. Funct. Models Neuropsychiatry 7, 37-60.

Pandey, U. B., and Nichols, C. D. (2011). Human disease models in Drosophila melanogaster and the role of the fly in therapeutic drug discovery. Pharmacol. Rev. 63, 411-436.

Panula, P., Aarnisalo, A. A., and Wasowicz, K. (1996). Neuropeptide FF, a mammalian neuropeptide with multiple functions. Prog. Neurobiol. 48, 461-487.

Pedrazzini, T. (2004). Importance of NPY Y1 receptor-mediated pathways: assessment using NPY Y1 receptor knockouts. Neuropeptides 38, 267-275.

Ranganathan, R., Sawin, E. R., Trent, C., and Horvitz, H. R. (2001). Mutations in the Caenorhabditis elegans serotonin reuptake transporter MOD-5 reveal serotonin-dependent and -independent activities of fluoxetine. J. Neurosci. 21, 5871-5884.

Reddy, K. C., Hunter, R. C., Bhatla, N., Newman, D. K., and Kim, D. H. (2011). Caenorhabditis elegans NPR-1-mediated behaviors are suppressed in the presence of mucoid bacteria. Proc. Natl. Acad. Sci. U.S.A. 108, 12887-12892.

Renn, S. C., Park, J. H., Rosbash, M., Hall, J. C., and Taghert, P. H. (1999). A pdf neuropeptide gene mutation and ablation of PDF neurons each cause severe abnormalities of behavioral circadian rhythms in Drosophila. Cell 99, 791-802.
Ringstad, N., and Horvitz, H. R. (2008). FMRFamide neuropeptides and acetylcholine synergistically inhibit egg-laying by C. elegans. Nat. Neurosci. 11, 1168-1176.

Rogers, C., Reale, V., Kim, K., Chatwin, H., Li, C., Evans, P., and de Bono, M. (2003). Inhibition of Caenorhabditis elegans social feeding by FMRFamide-related peptide activation of NPR-1. Nat. Neurosci. 6, 1178-1185.

Root, C. M., Ko, K. I., Jafari, A., and Wang, J. W. (2011). Presynaptic facilitation by neuropeptide signaling mediates odor-driven food search. Cell 145, 133-144.

Schneider, L. E., Sun, E. T., Garland, D. J., and Taghert, P. H. (1993). An immunocytochemical study of the FMRFamide neuropeptide gene products in Drosophila. J. Comp. Neurol. 337, 446-460.

Seroude, L. (2002). GAL4 drivers expression in the whole adult fly. Genesis 34, 34-38.

Simmer, F., Moorman, C., van der Linden, A. M., Kuijk, E., van den Berghe, P. V., Kamath, R. S., Fraser, A. G., Ahringer, J., and Plasterk, R. H. (2003). Genome-wide RNAi of C. elegans using the hypersensitive rrf-3 strain reveals novel gene functions. PLoS Biol. 1, e12. doi:10.1371/journal.pbio.0000012

Styer, K. L., Singh, V., Macosko, E., Steele, S. E., Bargmann, C. I., and Aballay, A. (2008). Innate immunity in Caenorhabditis elegans is regulated by neurons expressing NPR1/GPCR. Science 322, 460-464.

Sundaram, M., and Greenwald, I. (1993). Suppressors of a lin-12 hypomorph define genes that interact with both lin-12 and glp-1 in Caenorhabditis elegans. Genetics 135, 765-783.

Teng, M. S., Dekkers, M. P., Ng, B. L., Rademakers, S., Jansen, G., Fraser, A. G., and McCafferty, J. (2006). Expression of mammalian GPCRs in C. elegans generates novel behavioural responses to human ligands. BMC Biol. 4, 22. doi:10.1186/17417007-4-22

Teng, M. S., Shadbolt, P., Fraser, A. G., Jansen, G., and McCafferty, J. (2008). Control of feeding behavior in C. elegans by human G proteincoupled receptors permits screening for agonist-expressing bacteria. Proc. Natl. Acad. Sci. U.S.A. 105, 14826-14831.

Thorsell, A., and Heilig, M. (2002). Diverse functions of neuropeptide $\mathrm{Y}$ revealed using genetically modified animals. Neuropeptides 36 182-193.

Tobe, S. S., and Bendena, W. G. (2012) "Allatostatins in the insects," in The Handbook of Biologically Active Peptides, Chap. 31, ed. A. Kastin (MA, USA: Elsevier Science Press), 201-1206.

Vanden Broeck, J. (2001). Neuropeptides and their precursors in the fruitfly, Drosophila melanogaster. Peptides 22, 241-254.

Veenstra, J. A., Agricola, H., and Sellami, A. (2008). Regulatory peptides in fruit fly midgut. Cell Tissue Res. 334, 499-516.

Venken, K. J. T., Simpson, J. H., and Bellen, H. J. (2011). Genetic manipulation of genes and cells in the nervous system of the fruit fly. Neuron 72, 202-230.

Wang, C., Chin-Sang, I., and Bendena, W. G. (2012). The FGLamide-allatostatins influence foraging behavior in Drosophila melanogaster. PLoS ONE e36059. doi:10.1371/journal.pone 0036059

Wen, T. Q., Parrish, C. A., Xu, D., Wu, Q., and Shen, P. (2005). Drosophila neuropeptide $F$ and its receptor, NPFR1, define a signaling pathway that acutely modulates alcohol sensitivity. Proc. Natl. Acad. Sci. U.S.A. 102, 2141-2146.

Wu, Q., Wen, T. Q., Lee, G., Park, J. H., Cai, H. N., and Shen, P.
(2003). Developmental control of foraging and social behavior by the Drosophila neuropeptide Y-like system. Neuron 39, 147-161.

Wu, Q., Zhao, Z., and Shen, P. (2005). Regulation of aversion to noxious food by Drosophila neuropeptide Yand insulin-like systems. Nat. Neurosci. 8, 1350-1355.

Xu, J., Li, M., and Shen, P. (2010). A G-Protein-coupled neuropeptide Ylike receptor suppresses behavioral and sensory response to multiple stressful stimuli in Drosophila. J. Neurosci. 30, 2504-2512.

Yapici, N., Kim, Y. J., Ribeiro, C., and Dickson, B. J. (2008). A receptor that mediates the post-mating switch in Drosophila reproductive behaviour. Nature 451, 33-37.

Conflict of Interest Statement: The authors declare that the research was conducted in the absence of any commercial or financial relationships that could be construed as a potential conflict of interest.

Received: 13 March 2012; accepted: 14 July 2012; published online: 09 August 2012.

Citation: Bendena WG, Campbell J, Zara L, Tobe SS and Chin-Sang ID (2012) Select neuropeptides and their G-protein coupled receptors in Caenorhabditis elegans and Drosophila melanogaster. Front. Endocrin. 3:93. doi: 10.3389/fendo.2012.00093

This article was submitted to Frontiers in Experimental Endocrinology, a specialty of Frontiers in Endocrinology.

Copyright (c) 2012 Bendena, Campbell, Zara, Tobe and Chin-Sang. This is an open-access article distributed under the terms of the Creative Commons Attribution License, which permits use, distribution and reproduction in other forums, provided the original authors and source are credited and subject to any copyright notices concerning any third-party graphics etc. 